\title{
PORCUPINE IN FERRUGINOUS HAWK'S NEST
}

by Keith Hodson, 5191 Robertson Road, Ladner, B.C.

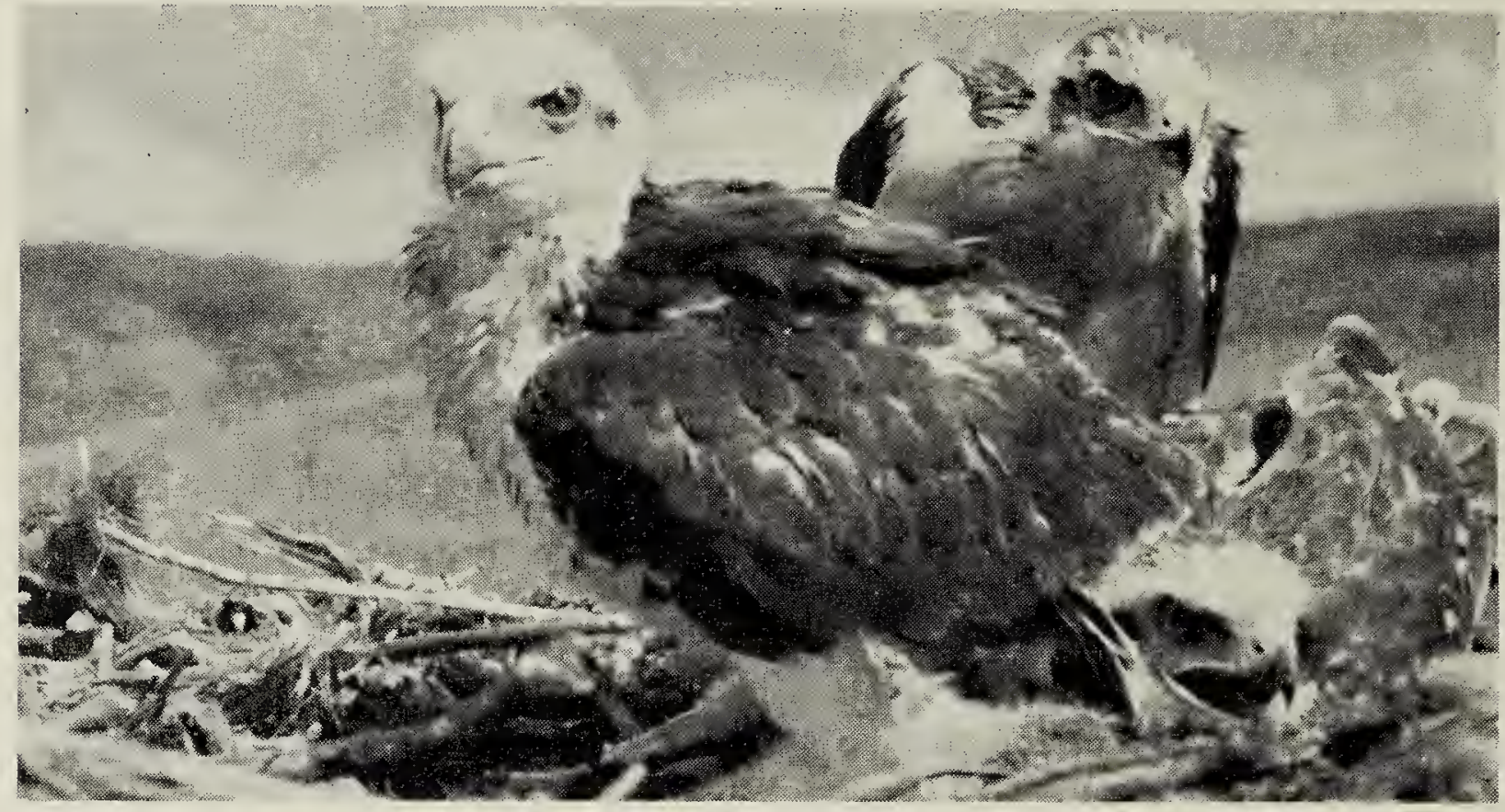

Ferruginous Hawks, Oldman River, Alberta

Photo by Keith Hodson

During the summer of 1968 I was working under the auspices of the Canadian Wildlife Service as a summer student on a survey of raptorial birds in the prairie provinces, and was fortunate to be able to visit the nesting sites of various species of birds of prey including Prairie Falcons, Pigeon Hawks, Sparrow Hawks, Red-tailed Hawks, Swainson's Hawks, and Ferruginous Hawks. One of the more interesting finds was the remains of a porcupine in a Ferruginous Hawk's nest along the Oldman River, Alberta, and porcupine quills in the young birds.

At the time of our visit the three young were just about ready to fly and one tumbled out of the nest on our appearance. I retrieved this one and John Cambell, who was assisting me, brought the other two down to our boat to be banded; it was then that John noticed what appeared to be a cactus spine in the cere of one. Upon pulling it out with the banding pliers, we discovered that in fact it was a porcupine quill which had already worked its way through the upper mandible into the mouth cavity. Upon close examination of the three birds, we found and removed a total of 24 quills. The following is a list of what was removed from each: female-nine quills (four through balls and joints of feet, one through upper mandible, one through wing butt, two into body in the anal area), first male-six quills (three through feet, one through leg joint, two deep into breast), second male-11 quills (four through balls and joints of feet, two into breast, two into back, three through wing butts). The female bird also had an old eye wound causing the eyelids to grow together, which we carefully cut apart.

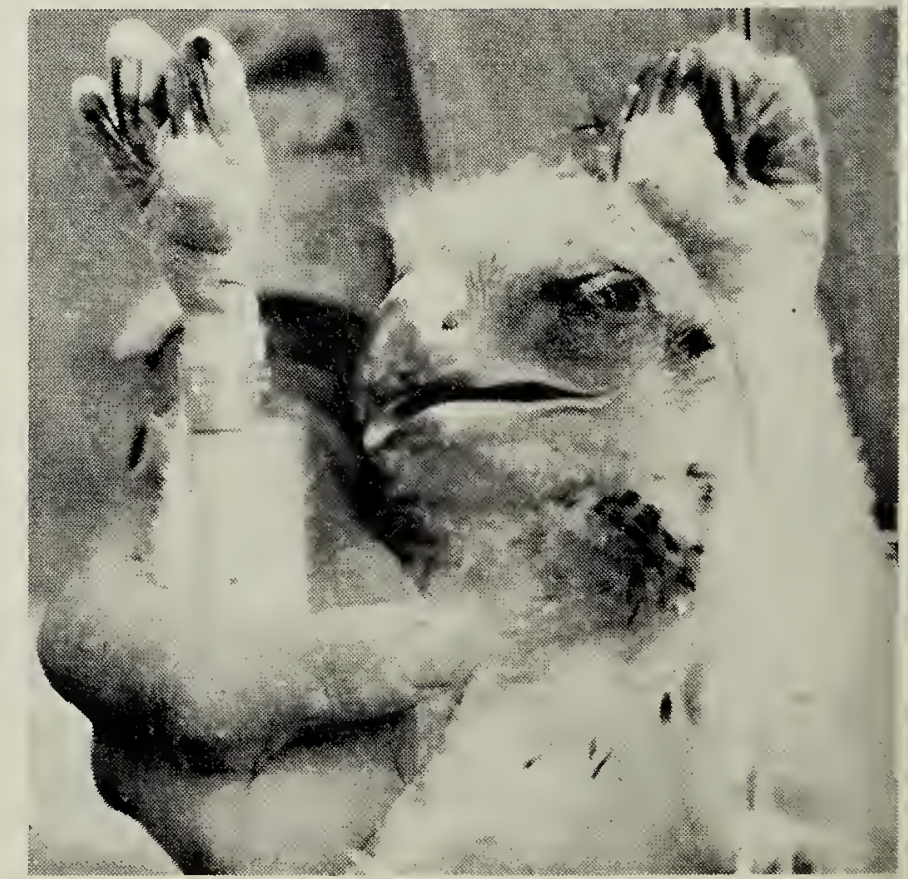

Porcupine quills in young Ferruginous Hawk 
We at first presumed that a porcupine had wandered into the nest, which was accessible from the top of the cliff, until we returned the young birds to their nest and found the remains of a porcupine in it. This poses a few interesting but unanswered, questions; did the adults actually kill the porcupine in search of food? had the porcupine been attacked and killed in defence of the nest? or had the adults found a dead porcupine and simply carried parts of it away to feed the young? In any case, one can only speculate as to what the condition of the adults is, or was. Other than the swellings where the quills had been pulled from, the young seemed in good shape, and the adults also showed no sign of handicap as they protested our presence at the eyrie.

\section{NEW SIGHTING OF BAND-TAILED PIGEON IN ALBERTA}

\section{by Michael Wilson, 196 Westover Drive, Calgary}

On August 16, 1968, at 4:30 p.m., my mother, Mrs. C. Eric Wilson, and I were walking along Ribbon Creek road in the front range country west of Calgary. We were about a halfmile west of the point where this road meets the Coleman-Kananaskis highway, 16 miles south of the latter's northern terminus on Highway 1 from Calgary to Banff. At this point, I spotted an unidentified pigeon, perched 30 feet up in a dead birch or poplar tree, some 60 yards away from us. Together we observed it for a short time with seven-power binoculars. After about three minutes, I attempted to make my way closer to the bird through an intervening deadfall, but the bird immediately flew away.

The observed characteristics of this bird were as follows:

1. Size comparable with that of the domestic Rock Dove: approximately 15 inches.

2. Overall coloration dominated by greys.

3. Tail broad and rounded, not pointed.

4. Tail marked with darker grey or black, but details uncertain due to shadow effects of a branch near the tail.

5. A distinct white collar or nape, well displayed because upper part of body was bathed in sunlight with no shadows.

6. Habitat: a forested intermontane valley.
7. Behaviour: perching in a tree, more wary than Rock Dove.

All of these characteristics agree well with descriptions of the Bandtailed Pigeon (Columba fasciata). The coloration, especially dark bands on the tail and the white nape, are pointed out by Peterson (1961, p. 149) as diagnostic of the species. Furthermore, Peterson states that the bird "might be mistaken for Rock Dove except for its woodland or mountain habitat and greater tendency to alight in trees."

This is the second record of the Band-tailed Pigeon from Alberta, and the first one from the mountains of the province. A specimen was secured on July 27, 1967, at Leduc, Alberta, by Mr. Harvey Burns (Halladay, 1968). The status of this species in Alberta is as yet undetermined.

The Band-tailed Pigeon is locally common in southwestern British Columbia, and is confined to that area west of the Cascade Mountains (Brooks and Swarth, 1925; p. 53). It is possible that prevailing westerly winds could facilitate the passage of some birds of this population over the mountains into Alberta.

\section{LITERATURE CITED}

Brooks, Allan, and H. S. Swarth. 1925. A distributional list of the birds of British Columbia. Cooper Ornithological Club. Pacific Coast Avifauna, Number 17.

Halladay, I.A.R. (Ed.). 1968. Band-tailed Pigeon added to Alberta list. Calgary Bird Club Bulletin, Number 65, p. 4.

Peterson, Roger Tory. 1961. A field guide to western birds. Houghton Mifflin Co., Boston. 